\title{
UJI EFEKTIVITAS EKSTRAK DAUN CENGKEH (Syzygium aromaticum) SEBAGAI BAHAN DASAR OBAT NYAMUK ELEKTRIK CAIR TERHADAP NYAMUK Aedes aegypti
}

\section{THE EFFECTIVENESS TEST OF CLOVE LEAVE EXTRACTS (Syzygium aromaticum) AS MATERIAL OF ELEKTRIK LIQUID VAPORIZER AGAINST Ae. Aegypti}

\author{
Sasono Handito ${ }^{1}$, Endah Setyaningrum ${ }^{1}$, Tundjung T, Handayani ${ }^{1}$ \\ 1Jurusan Biologi FMIPA Universitas Lampung \\ Jurusan Biologi FMIPA, Universitas Lampung \\ Jl. Prof.Dr. SoemantriBrojonegoro No. 1, Bandarlampung, Lampung, Indonesia, 35145
}

\begin{abstract}
Abstrak
Aedes aegypti merupakan vektor penyakit Demam Berdarah Dengue (DBD) yang masih menjadi masalah kesehatan di Indonesia. Upaya pengendalian dan pemberantasan Ae. aegypti saat ini banyak dilakukan, salah satunya dengan menggunakan insektisida kimiawi. Penggunaan insektisida kimiawi secara berkelanjutan menimbulkan resistensi pada nyamuk vektor. Telah diketahui bahwa daun tanaman cengkeh (Syzygium aromaticum L) mengandung flavonoid dan saponin yang berpotensi sebagai insektisida. Untuk membuktikan hal tersebut dilakukan penelitian yang bertujuan untuk mengetahui efektifitas dari ekstrak daun cengkeh dengan menuntukan nilai Lethal Concentration ( $\mathrm{LC}_{50}$ dan $\mathrm{LC}_{90}$ ) dan Lethal Time ( $\mathrm{LT}_{50}$ dan $\mathrm{LT}_{90}$ ). Penelitian eksperimen yang menggunakan rancangan acak kelompok ini dilakukan dengan lima konsentrasi, yaitu; $10 \%$; $20 \%$; $30 \%$; $40 \%$; dan $50 \%$ ekstrak daun cengkeh, dan dengan dua kontrol yaitu, kontrol negatif yang berisi aquades, kontrol positif yang berisi tranflutrin $12,38 \mathrm{~g} / \mathrm{l}$, dengan empat kali pengulangan setiap konsentrasi dan kontrol. Pengamatan terhadap jumlah nyamuk yang mati setiap $5,10,20,40,60$, 120, 240, 480, dan 1440 menit setelah perlakuan. Dari hasil Uji ANOVA yang diuji lanjut dengan Uji BNT diketahui bahwa konsentrasi yang paling efektif dibandingkan kontrol negatif dan sama dengan kontrol positif adalah 50\%. Dari analisis probit diperoleh nilai $\mathrm{LC}_{50}$ sebesar $43,709 \%$, sedangkan untuk nilai LC 90 sebesar 49,069\%. Nilai $\mathrm{LT}_{50}$ dan $\mathrm{LT}_{90}$ dari penelitian ini adalah 1220,152 menit dan 1126,488 menit. Kesimpulan dari penelitian ini adalah ekstrak daun cengkeh berpotensi sebagai insektisida terhadap Ae. aegypti, dan konsentrasi ekstrak yang paling efektif adalah konsentrasi sebesar $50 \%$.
\end{abstract}

Kata kunci : daun cengkeh (Syzygium aromaticum L), Ae. aegypty, ekstrak daun cengkeh

\begin{abstract}
Aedes aegypti is dengue fever vector which still be a public health problem in Indonesia. Chemical insecticides are the most commonly used as inseccide to control and eradicate Ae. aegypti. However, the long use of chemical inseccides can caused resistance for these vectors. The leaves of clove (Syzygium aromaticum L) known contains flavonoids and saponins that have potentially as inseccides. This research objective was to know the effectivenes of clove leaves extract as inseccide for $A e$. aegypti, to know Lethal Concentration value ( $\mathrm{LC}_{50}$ and $\left.\mathrm{LC}_{90}\right)$ and Lethal Time value ( $\mathrm{LT}_{50}$ and $\left.\mathrm{LT}_{90}\right)$. The experiment us a randomized blok design with five levels of concentration, $10 \% ; 20 \% ; 30 \% ; 40$ $\%$; and $50 \%$ of the clove leaf extract, and with two control, negative control containing aquades, and positif control containing tranflutrin $12,38 \mathrm{~g} / \mathrm{l}$, with four times repetition at each concentration and control. Oservation was done at 5, 10, 20, 40, 60, 120, 240, 480, and 1440 minutes after application. ANOVA Test and BNT Test resulted the most effective concentration than negatif controls and equel with positive control was $50 \%$. Probit analysis result showed that $\mathrm{LC}_{50}$ value was $43,709 \%$ and $\mathrm{LC}_{90}$ value was $49,069 \%$. $L T_{50}$ value and $\mathrm{LT}_{90}$ in this research are 1220,152 minutes and 1126,488 minutes. The results of this research showed that clove leaves extract is potential as inseccides for Ae. aegypti and the most effective extract was $50 \%$.
\end{abstract}

Keywords: Clove leaf (Syzygium aromaticum L), Ae. aegypty, Clove leaf extract

\section{PENDAHULUAN}

Penyakit demam berdarah dengue (DBD) merupakan penyakit yang berkaitan erat dengan kenaikan populasi vektor Ae. aegypty.
Menurut Wijana, (1982) Ae. aegypty adalah satu-satunya vektor dari virus dengue. Beberapa penelitian lainnya membuktikan bahwa disamping Ae. aegypty, spesies-spesies Aedes $s p$. yang lain dapat menjadi vektor penyakit ini 
diantaranya Ae. albopictus. Akan tetapi Ae. aegypti lebih berperan dalam penularan penyakit DBD dibandingkan dengan nyamuk Ae. albopictus, karena nyamuk Ae. aegypti hidupnya di dalam dan di sekitar rumah, sedangkan Ae. albopictus hidupnya di kebun, sehingga jarang kontak dengan manusia.

Insektisida berbahan dasar kimia untuk membasmi nyamuk telah banyak digunakan, tetapi pada umumnya produk-produk semacam itu bersifat toksik, meninggalkan bau, dapat menyebabkan iritasi pada kulit, resistensi serangga, pencemaran lingkungan, dan meracuni makhluk hidup lain yang bukan sasaran. Hal-hal semacam itu dapat diatasi salah satunya dengan menggunakan insektisida alami yang umumnya berasal dari tumbuhan, karena memiliki tingkat keamanan yang lebih tinggi, yaitu mudah terurai di alam dan tidak menimbulkan bahaya residu yang berat dan tentunya aman bagi makhluk hidup dan lingkungan (Kardinan, 2005).

Menurut Subiyakto (2005), insektisida nabati dapat dibuat dari beberapa bagian tanaman, yakni akar, umbi, batang, daun, biji dan buah dengan teknologi sederhana, seperti berupa larutan hasil perasan, perendaman, ekstrak, dan rebusan.

Salah satu tanaman yang dapat dijadikan sebagai bahan insektisida nabati adalah tanaman cengkeh. Daun tanaman cengkeh memiliki kandungan bahan aktif seperti senyawa eugenol, saponin, flavonoid dan tanin (Dalimarta dan Hembing, 1994). Bahan aktif yang terkandung pada daun cengkeh tersebut dapat mempengaruhi beberapa aktifitas fisik serangga, seperti penghambatan aktifitas makan, pernapasan, pertumbuhan dan perkembangan, serta kematian atau mortalitas serangga (Dadang dan Prijono, 2008).

Dua prinsip dasar dalam penggunaan insektisida nabati adalah efektif dan efisien. Keefektifan tersebut dilihat dari nilai LC (Lethal Concentration) dan LT (Lethal Time). LC50 dan $\mathrm{LC}_{90}$ adalah konsentrasi yang dapat membunuh $50 \%$ dan $90 \%$ dari jumlah Ae. aegypti yang diuji, sedangkan $\mathrm{LT}_{50}$ dan $\mathrm{LT}_{90}$ adalah waktu yang diperlukan untuk membunuh $50 \%$ dan $90 \%$ dari jumlah Ae. aegypti yang diuji pada konsentrasi tertentu (Guomin dkk, 2003). LC dan LT dapat dihitung dengan menggunakan analisis probit. Pemakaian istilah LC lebih dipilih daripada istilah LD (Lethal Dose) karena pada penelitian ini sulit untuk menentukan dosis (jumlah kandungan ekstrak yang masuk ke dalam tubuh serangga), sehingga lebih dipilih istilah Lethal Concentration yang secara tepat menggambarkan kosentrasi eksrak pada media percobaan (Ardianto, 2008).

\section{BAHAN dan METODE}

Telah dilakukan penelitian pada bulan September-Oktober 2014 di Laboratorium Zoologi dan Laboratorium Kimia Organik FMIPA Universitas Lampung. Penelitian dilaksanakan dengan menggunakan metode Rancangan Acak kelompok (RAK) dengan 5 taraf konsentrasi ekstrak yaitu; $10 \%$; $20 \%$; $30 \%$; $40 \%$; dan $50 \%$ ekstak daun cengkeh, dan dengan 2 kontrol yaitu; kontrol negatif yang berisi aquades dan kontrol positif yang berisi tranflutrin $12,38 \mathrm{~g} / \mathrm{l}$. Masing-masing perlakuan dan kontrol dilakukan 4 kali pengulangan.

Pembuatan ekstrak daun cengkeh menggunakan metode maserasi dan pelarut etanol $96 \%$ sebanyak $6.000 \mathrm{~mL}$. Daun cengkeh tua dengan berat 1.500 gram dikering-anginkan dalam ruangan sampai didapat berat kering daun cengkeh sebesar 749,2 gram, kemudian diblender tanpa menggunakan air, selanjutnya direndam dalam pelarut etanol $96 \%$ sebanyak 6.000 $\mathrm{mL}$ selama 24 jam. Rendaman tersebut kemudian disaring dengan kertas saring untuk mendapatkan ekstrak yang diinginkan. Hasil ekstraksi kemudian dipekatkan dengan vacum rotary evaporator sehingga diperoleh ekstrak daun cengkeh dengan konsentrasi 100\% dengan berat 76,4118 gram (Depkes RI, 1986). Hasil ekstraksi kemudian diencerkan dengan akuades agar diperoleh konsentrasi $10 \%$; $20 \%$; $30 \%$; $40 \%$; dan $50 \%$ (konsentrasi ditentukan berdasarkan uji pendahuluan yang telah dilakukan sebelumnya).

Ekstrak dengan lima konsentrasi, yaitu $10 \%$, $20 \%, 30 \%, 40 \%$, dan $50 \%$ ekstrak daun cengkeh, dan dengan dua kontrol yaitu, kontrol negatif yang berisi aquades, kontrol positif yang berisi tranflutrin 12,38 $\mathrm{g} / \mathrm{l}$, dimasukkan pada masing-masing kotak pengamatan. Kemudian 20 ekor nyamuk Ae. aegypti diletakkan ke dalam masing-masing kotak pengamatan yang telah berisi berbagai konsentrasi ekstrak daun cengkeh. Setiap perlakuan diulang sebanyak empat kali pengulangan setiap konsentrasi dan kontrol. Pengamatan terhadap jumlah nyamuk yang mati setiap 5, 10, 20, 40,60, 120, 240, 480, dan 1440 menit setelah perlakuan.

Hasil pengamatan yang diperoleh dianalisa dengan menggunakan uji analisis ANOVA dilanjutkan dengan uji BNT, agar dapat mengetahui adanya perbedaan rata-rata kematian nyamuk di setiap perlakuan dan masing-masing kontrol yang diberikan. Kemudian dilakukan uji dengan menggunakan analisis Probit untuk 
mengetahui Lethal Concentration ( $\mathrm{LC}_{50}$ dan LC 90 ) dan Lethal Time ( $\mathrm{LT}_{50}$ dan $\mathrm{LT}_{90}$ ).

\section{Hasil dan Pembahasan}

\section{Uji Efektivitas}

Hasil penelitian ini menunjukkan bahwa ratarata kematian tertinggi terdapat pada konsentrasi $50 \%$ yaitu $98,75 \%$ dan rata-rata kematian terrendah terdapat pada konsentrasi $10 \%$ yaitu sebanyak $18,75 \%$. Hal tersebut menunjukkan bahwa tingginya angka kematian nyamuk uji bergantung pada besar konsentrasi ekstrak yang diberikan dan lamanya waktu pemaparan (Riyanti, 2005). Dari hasil pengamatan dapat diketahui bahwa ada korelasi antara besar konsentrasi dengan daya bunuh yang ditimbulkan. Hal ini dapat dilihat dari besarnya nilai $r$ yaitu 0,967 . Sehingga semakin tinggi konsentrasi ekstrak daun cengkeh yang diberikan maka semakin tinggi pula tingkat kematian pada nyamuk uji (Gambar 1).

Hasil uji ANOVA yang diuji lanjut dengan Uji BNT (Beda Nyata Terkecil) (Tabel 1) menunjukkan bahwa terjadi kematian nyamuk uji tertinggi pada konsentrasi ekstrak 50\%. Berdasarkan hasil analisis menunjukkan bahwa kematian nyamuk uji pada konsentrasi ekstrak $50 \%$ tidak berbeda nyata dengan kontrol positif sehingga pada kosentrasi $50 \%$ ekstrak daun cengkeh memiliki potensi yang sama dengan kontrol positif. Berdasarkan hasil dari analisis ANOVA, konsentrasi $50 \%$ merupakan konsentrasi ekstrak daun cengkeh yang paling efektif bagi nyamuk Ae. aegypti jika dibandingkan dengan konsentrasi lainnya. Dengan kata lain bahwa ekstrak daun cengkeh dengan konsentrasi $50 \%$ sudah memiliki daya bunuh yang tinggi terhadap nyamuk $A e$. aegypti. Tingginya angka kematian nyamuk uji pada konsentrasi ekstrak $50 \%$ disebabkan oleh banyaknya jumlah senyawa aktif yang kontak langsung dengan nyamuk uji selama waktu pemaparan.

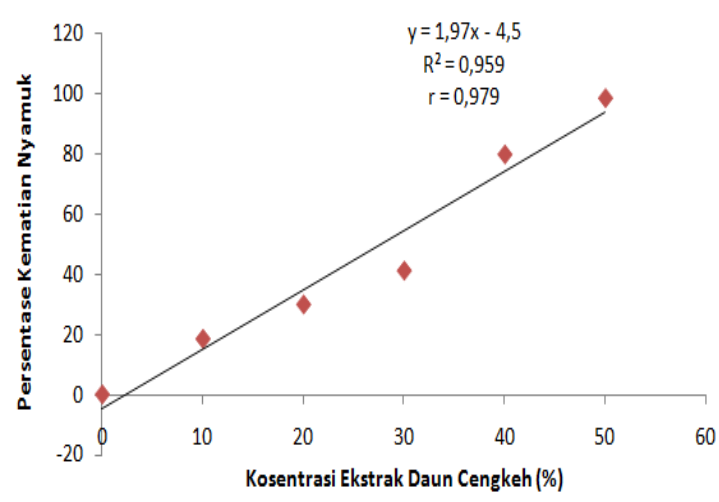

Gambar 1. Pengaruh konsentrasi ekstrak daun cengkeh terhadap kematian nyamuk uji setelah 1440 menit (24 jam)

Konsentrasi 50\% merupakan konsentrasi yang paling kental dan bau yang dihasilkan dari ekstrak daun cengkeh, begitu kuat sehingga racun dalam ekstrak daun cengkeh yang masuk ke dalam tubuh nyamuk bersamaan dengan udara masuk melalui mulut menyebabkan racun menyerang usus tengah yang berfungsi mengabsorpsi makanan sehingga menyebabkan kematian pada Ae. aegypti (Muhaeni, 2007).

Tabel 1. Hasil uji Anova yang diuji lanjut dengan Uji BNT (Beda Nyata Terkecil)

\begin{tabular}{cccccccc}
\hline $\begin{array}{c}\text { Menit } \\
\text { Ke- }\end{array}$ & \multicolumn{7}{c}{ Kosentrasi } \\
\cline { 2 - 7 } & $(-)$ & $10 \%$ & $20 \%$ & $30 \%$ & $40 \%$ & $50 \%$ & $(+)$ \\
\hline 5 & $0,00 \pm 0,00 \mathrm{a}$ & $0,00 \pm 0,00 \mathrm{a}$ & $0,00 \pm 0,00 \mathrm{a}$ & $0,00 \pm 0,00 \mathrm{a}$ & $0,00 \pm 0,00 \mathrm{a}$ & $5,00 \pm 4,08 \mathrm{~b}$ & $45,00 \pm 0,00 \mathrm{c}$ \\
10 & $0,00 \pm 0,00 \mathrm{a}$ & $0,00 \pm 0,00 \mathrm{a}$ & $0,00 \pm 0,00 \mathrm{a}$ & $0,00 \pm 0,00 \mathrm{a}$ & $2,50 \pm 2,88 \mathrm{a}$ & $8,75 \pm 2,50 \mathrm{~b}$ & $87,50 \pm 2,88 \mathrm{c}$ \\
20 & $0,00 \pm 0,00 \mathrm{a}$ & $0,00 \pm 0,00 \mathrm{a}$ & $0,00 \pm 0,00 \mathrm{a}$ & $0,00 \pm 0,00 \mathrm{a}$ & $10,00 \pm 4,08 \mathrm{~b}$ & $17,50 \pm 2,88 \mathrm{c}$ & $100,0 \pm 0,00 \mathrm{~d}$ \\
40 & $0,00 \pm 0,00 \mathrm{a}$ & $0,00 \pm 0,00 \mathrm{a}$ & $0,00 \pm 0,00 \mathrm{a}$ & $3,75 \pm 2,50 \mathrm{a}$ & $21,25 \pm 2,50 \mathrm{~b}$ & $40,00 \pm 5,77 \mathrm{c}$ & $100,0 \pm 0,00 \mathrm{~d}$ \\
60 & $0,00 \pm 0,00 \mathrm{a}$ & $1,25 \pm 2,50 \mathrm{a}$ & $5,00 \pm 4,08 \mathrm{a}$ & $8,75 \pm 2,50 \mathrm{ab}$ & $35,00 \pm 4,08 \mathrm{c}$ & $73,75 \pm 2,50 \mathrm{~d}$ & $100,0 \pm 0,00 \mathrm{e}$ \\
120 & $0,00 \pm 0,00 \mathrm{a}$ & $5,00 \pm 4,08 \mathrm{~b}$ & $13,75 \pm 2,50 \mathrm{c}$ & $18,75 \pm 2,50 \mathrm{~d}$ & $53,75 \pm 2,50 \mathrm{e}$ & $83,75 \pm 2,50 \mathrm{f}$ & $100,0 \pm 0,00 \mathrm{~g}$ \\
240 & $0,00 \pm 0,00 \mathrm{a}$ & $8,75 \pm 2,50 \mathrm{~b}$ & $17,50 \pm 2,88 \mathrm{c}$ & $27,50 \pm 2,88 \mathrm{~d}$ & $58,75 \pm 2,50 \mathrm{e}$ & $87,50 \pm 2,88 \mathrm{f}$ & $100,0 \pm 0,00 \mathrm{~g}$ \\
480 & $0,00 \pm 0,00 \mathrm{a}$ & $12,50 \pm 2,88 \mathrm{~b}$ & $22,50 \pm 2,88 \mathrm{c}$ & $36,25 \pm 2,50 \mathrm{~d}$ & $71,25 \pm 2,50 \mathrm{e}$ & $96,25 \pm 2,50 \mathrm{f}$ & $100,0 \pm 0,00 \mathrm{~g}$ \\
1440 & $0,00 \pm 0,00 \mathrm{a}$ & $18,75 \pm 2,50 \mathrm{~b}$ & $30,00 \pm 4,08 \mathrm{c}$ & $41,25 \pm 2,50 \mathrm{~d}$ & $80,00 \pm 4,08 \mathrm{e}$ & $98,75 \pm 2,50 \mathrm{f}$ & $100,0 \pm 0,00 \mathrm{f}$
\end{tabular}

Keterangan : Nilai rata-rata yang diikuti huruf yang sama pada baris yang sama tidak berbeda nyata pada taraf $\alpha=5 \%$ pada uji lanjut BNT.

Menurut Nurdjannah (2004) Flavonoid berfungsi sebagai inhibitor pernapasan sehingga saat nyamuk $A e$. aegypti melakukan pernapasan flavonoid akan masuk bersama udara $\left(\mathrm{O}_{2}\right)$ melalui alat pernapasannya. Setelah nyamuk melakukan pernapasan maka flavonoid akan bekerja menghambat sistem kerja pernapasan di dalam tubuh nyamuk Ae. aegypti, karena 
menurut Djojosumarto (2008) senyawa flavonoid inilah yang dapat digunakan dalam membunuh nyamuk Ae. aegypti saat dilakukan pengujian.

Menurut Ferdinanti (2001) selain Flavonoid daun cengkeh juga mengandung senyawa lain yang dapat membunuh nyamuk Ae. aegypti yaitu, senyawa eugenol, saponin dan tanin. Eugenol yang dapat merusak mukosa kulit nyamuk, menyebabkan kerusakan pada kutikula nyamuk dan mengganggu saluran pernafasan pada nyamuk. Sedangkan saponin bekerja dengan cara menurunkan tegangan permukaan tubuh nyamuk sehingga mempermudah proses penyerapan bahan aktif sehingga aktivitas insektisida dapat bekerja secara optimal. Sedangkan Tanin dapat menurunkan kemampuan mencerna makanan dengan cara menurunkan aktivitas enzim pencernaan (protease dan amilase) serta mengganggu aktivitas protein usus. Serangga yang memakan tumbuhan dengan kandungan tanin tinggi akan memperoleh sedikit makanan, akibatnya akan terjadi penurunan pertumbuhan.

Menurut WHO (2005), insektisida dianggap memiliki efek apabila menyebabkan kematian nyamuk uji sebesar $10-95 \%$ selama 24 jam, sedangkan Komisi Pestisida (1995) menyatakan bahwa penggunaan insektisida dikatakan efektif apabila dapat mematikan $90-100 \%$ nyamuk uji selama 24 jam. Pada pengamatan terlihat bahwa pada konsentrasi ekstrak daun cengkeh $50 \%$ yang mampu membunuh lebih dari $90 \%$ nyamuk uji sehingga dapat dikatakan bahwa ekstrak daun cengkeh memiliki efektivitas sebagai insektisida.

\section{Lethal Concentration 50\% (LC $\mathrm{LC}_{50}$ ) dan $\mathbf{9 0 \%}$ (LC90)}

Lethal Concentration merupakan suatu ukuran untuk mengukur daya toksisitas suatu jenis insektisida, yang ditentukan berdasarkan jumlah kematian Ae. aegypti pada setiap konsentrasi. Nilai $\mathrm{LC}_{50}$ dan $\mathrm{LC}_{90}$ merupakan konsentrasi yang dibutuhkan untuk membunuh $50 \%$ dan $90 \%$ dari jumlah $A e$. aegypti yang diuji. Nilai $\mathrm{LC}_{50}$ dan $\mathrm{LC}_{90}$ diperoleh dari analisis probit dengan menggunakan program SPSS 19.00 . Di bawah ini disajikan hasil analisis probit berdasarkan lamanya waktu pengamatan dari jumlah nyamuk yang mati karena pengaruh kosentrasi ekstrak daun cengkeh.

Nilai $\mathrm{LC}_{50}$ dan $\mathrm{LC}_{90}$ yang diperoleh dari analisis probit menunjukkan bahwa semakin lama konsentrasi ekstrak daun cengkeh yang diberikan maka semakin kecil pula konsentrasi yang dibutuhkan untuk membunuh $50 \%$ dan $90 \%$ nyamuk uji. Hal ini disebabkan karena semakin besar konsentrasi maka toksisitas ekstak daun cengkeh terhadap Ae. aegypti akan semakin besar sehingga jumlah kematian semakin meningkat. Hal ini dapat dilihat pada Tabel 2 dimana nilai $\mathrm{LC}_{50}$ dan $\mathrm{LC}_{90}$ dari menit ke-5 sampai menit ke-1440 semakin menurun konsentrasinya (Hoedojo, 2008).

Tabel 2. Nilai $\mathrm{LC}_{50}$ dan $\mathrm{LC}_{90}$ Ae. aegypti pada berbagai waktu pengamatan

\begin{tabular}{cccc}
\hline No & Waktu (menit) & LC $_{50}(\%)$ & LC $_{90}(\%)$ \\
\hline 1 & 5 & 72,56 & 90,34 \\
2 & 10 & 67,61 & 84,58 \\
3 & 20 & 61,95 & 80,15 \\
4 & 40 & 52,25 & 68,69 \\
5 & 60 & 43,71 & 59,84 \\
6 & 120 & 38,18 & 56,79 \\
7 & 240 & 35,49 & 55,66 \\
8 & 480 & 31,16 & 49,07 \\
9 & 1440 & 27,99 & 46,05 \\
\hline
\end{tabular}

Adapun nilai $\mathrm{LC}_{50}$ yang diperoleh dalam penelitian ini adalah sebesar $43,71 \%$ pada menit ke-60 sedangkan nilai $\mathrm{LC}_{90}$ dalam penelitian ini adalah $49,07 \%$ pada menit ke480. Nilai $L C_{50}$ dan $L C_{90}$ tersebut menunjukkan bahwa kandungan ekstrak daun cengkeh yang terkandung dalam $45 \mathrm{ml}$ larutan ekstrak daun cengkeh merupakan batas kosentrasi minimum yang dibutuhkan untuk dapat membunuh hingga $50 \%$ dan $90 \%$ nyamuk Ae. aegypti

Hasil penelitian lain menggunakan tumbuhan berbeda yaitu ekstak kulit langsat (L. Domesticum) yang paling efektif dengan $\mathrm{LC}_{50}$ sebesar $41,49 \%$ pada menit ke-60 (Mirnawati, 2004). Ekstrak daun cengkeh mempunyai aktivitas insektisida yang lebih rendah dibandingkan ekstak kulit langsat yaitu dengan nilai $\mathrm{LC}_{50}$ sebesar $43,71 \%$. Padahal kandungan saponin dan flavonoid dalam daun cengkeh lebih tinggi dari pada ekstak kulit langsat. Hal ini kemungkinan disebabkan pada penelitian ini, ektrak daun cengkeh hanya dilarutkan dalam aquades sehingga pada saat diuapkan saponin dan flavonoid hanya sedikit yang bisa terurai, sedangkan pada percobaan ekstak kulit langsat digunakan pelarut akohol $70 \%$ sehingga eugenol dan flavonoid dapat menguap secara sempurna (Mirnawati, 2004).

Meskipun kosentrasi dan waktu yang dibutuhkan oleh ekstrak daun cengkeh untuk membunuh nyamuk $A e$. aegypti lebih kecil dan lebih lama dibandingkan dengan insektisida sintetis, namun pengggunaan ekstrak daun cengkeh sebagai bioinsektisida lebih aman dan ekologis dibandingkan dengan insektisida sintetis. Hal tersebut dikarenakan sifat ekstrak 
daun cengkeh yang spesifik, yaitu hanya membunuh organisme sasaran (Sukrasno 2001). Bahan aktif ekstrak daun cengkeh yang berasal dari alam membuat penggunaan ekstrak daun cengkeh sebagai bioinsektisida lebih mudah terdegredasi oleh alam dan tidak meninggalkan bahan residu terakumulasi pada air, tumbuhan dan hewan lain. Sehingga penggunaan ekstrak daun cengkeh sebagai bioinsektisida aman bagi manusia dan lingkungan (Hoedojo, 2008).

\section{Lethal Time $\mathbf{5 0 \%}\left(\mathrm{LT}_{50}\right)$ dan $\mathbf{9 0} \%$ (LT 90$)$}

Nilai $\mathrm{LT}_{50}$ dan $\mathrm{LT}_{90}$ merupakan waktu yang dibutuhkan untuk membunuh $50 \%$ dan $90 \%$ dari jumlah $A e$. aegypti yang diuji pada konsentrasi tertentu. Nilai $\mathrm{LT}_{50}$ dan $\mathrm{LT}_{90}$ diperoleh dengan menggunakan program analisis Probit. Hasil analisis probit untuk $\mathrm{LT}_{50}$ dan $\mathrm{LT}_{90}$ dapat dilihat pada Tabel 3 berikut :

Tabel 3. Nilai $\mathrm{LT}_{50}$ dan $\mathrm{LT}_{90}$ kematian Ae. aegypti pada berbagai konsentrasi ekstrak daun cengkeh

\begin{tabular}{cccc}
\hline No & Konsentrasi & $\mathrm{LT}_{50}$ (menit) & $\mathrm{LT}_{90}$ (menit) \\
\hline 1 & $10 \%$ & 1820,44 & 2874,59 \\
2 & $20 \%$ & 1472,65 & 2575,50 \\
3 & $30 \%$ & 1220,15 & 2274,30 \\
4 & $40 \%$ & 550,20 & 1604,36 \\
5 & $50 \%$ & 72,34 & 1126,49 \\
\hline
\end{tabular}

menunjukkan bahwa semakin tinggi konsentrasi ekstrak daun cengkeh yang diberikan maka semakin sedikit juga waktu yang diperlukan untuk membunuh 50\% nyamuk Ae. aegypti. Dari hasil analisis dengan menggunakan program analisis Probit pada konsentrasi ekstrak $10 \%$ dan $20 \%$ diperoleh nilai $\mathrm{LT}_{50}$ yang melebihi batas waktu pengamatan yaitu 1440 menit (1 hari) sehingga pada konsentrasi tersebut ekstrak daun cengkeh belum efektif jika digunakan sebagai insektisida, karena pada waktu 1 hari belum mengakibatkan kematian $50 \%$ total nyamuk uji. Namun nilai $\mathrm{LT}_{50}$ pada konsentrasi ekstrak 30\%, 40\% dan 50\% lebih rendah dari batas waktu pengamatan.

Menurut Hoedojo (2008) Terjadinya penurunan nilai $L T_{50}$ pada konsentrasi tersebut dikarenakan besarnya konsentrasi yang diberikan terhadap nyamuk uji menyebabkan efek toksik pada ekstrak daun cengkeg semakin besar pula sehingga hanya dibutuhkan waktu yang sedikit untuk membunuh $50 \%$ nyamuk uji.

Pada penelitian ini juga didapatkan nilai $\mathrm{LT}_{90}$ yang semakin menurun jika dibandingkan dengan peningkatan kosentrasi ekstrak daun cengkeh (Tabel 3). Hal ini memperlihatkan bahwa semakin tinggi kosentrasi yang diberikan pada nyamuk uji, semakin banyak kandungan kimia yang terpapar pada nyamuk uji, sehingga waktu yang dibutuhkan untuk membunuh nyamuk menjadi semakin cepat. Pada LT90 hanya kosentrasi $50 \%$ dapat mencapai kematian nyamuk sebesar $90 \%$, pada menit ke-1126,49

\section{SIMPULAN}

1. Ekstrak daun cengkeh dengan konsentrasi $50 \%$ efektif sebagai insektisida terhadap nyamuk Ae. aegypti.

2. Nilai $L_{50}$ ekstrak daun cengkeh sebagai insektisida terhadap nyamuk Ae. aegypti adalah $43,709 \%$ pada menit ke-60 sedangkan nilai LC $_{90}$ adalah $49,069 \%$ pada menit ke-480

3. Nilai $L_{50}$ ekstrak daun cengkeh sebagai insektisida terhadap nyamuk Ae. aegypti adalah 1220,152 menit pada konsentrasi $30 \%$, sedangkan nilai $\mathrm{LT}_{90}$ adalah 1126,488 menit pada kosentrasi 50\%

\section{DAFTAR PUSTAKA}

Ardianto, T. 2008. Pengaruh Ekstrak Bunga Cengkeh (Syzygium aromaticum L.) terhadap Mortalitas Larva Aedes aegypti. (Skripsi). Fakultas Kedokteran Universitas Sebelas Maret.

Dadang, P. dan Prijono, D. 2008. Insektisida Nabati : Prinsip, Pemanfaatan, dan Pengembangan. Departemen Proteksi Tanaman. Institut Pertanian Bogor. Bogor.

Dalimarta, S. dan Hembing, W. 1994. Tanaman Berkhasiat Obat di Indonesia jilid ke-3. Pustaka Kartini. Jakarta.

Fairuz, H. 2008. Pengaruh Ekstrak Bunga Cengkeh (Syzygium aromaticum) terhadap Mortalitas Larva Aedes aegypti L. (Skripsi). Fakultas Kedokteran Universitas Sebelas Maret.

Ferdinanti, E, 2001. Uji aktivitas antibakteri obat kumur minyak cengkeh (Syzygium aromaticum (L) Merr \& Perry) asal bunga, tangkai bunga, dan daun cengkeh terhadap bakteri. (Skripsi). Fakultas Matematika dan Pengetahuan Alam. Institut Sains dan Teknologi Nasional. Jakarta.

Guomin, J., Xiaolin, Y., and Rongchang, C. 2003. The Handbook of Insecticide

Formulations and Its Technologies for Household and Public Health Uses. Hong Kong: Jin Tai Printing Ltd.

Hoedojo, R. 2008 Morfologi, Daur Hidup, dan Perilaku Nyamuk: Parasitologi Kedokteran Edisi Ke-4. Fakultas Kedokteran Universitas Indonesia. Jakarta. 
Kardinan, A. 2005. Tanaman Pengusir dan Pembasmi Nyamuk Vol II. Agro Media Pustaka. Jakarta.

Komisi Pestisida. 2005 Metode Standar Pengujian Efikasi Pestisida. Bandung. Komisi Pestisida Bandung.

Mirnawati, S. 2004. Pengaruh Ekstak Kulit Langsat (L. domesticum) terhadap Mortalitas Larva Ae. aegypti. (Skripsi). Fakultas Pertanian Universitas Indonesia. Jakarta.

Muhaeni, D. 2007. Membuat dan Memanfaatkan Pestisida Ramah Lingkungan. Agro Media Pustaka. Jakarta.

Nurdjannah, N. 2004. Diversifikasi Penggunaan Cengkeh. Balai Besar Penelitian dan pengembangan Pasca Panen Pertanian. Bogor.

Riyanti, H. 2005. Toksikologi Limbah Cair Kelapa Sawit terhadap Ikan Nila (Aeromonas sp). (Skripsi). FKIP Universitas Riau. Pekanbaru.

Subiyakto. 2005. Pestisida Nabati: Pembuatan dan Pemanfaatannya. Penerbit Kanisius. jakarta.

Sukrasno, S. 2001. Cengkeh, Tanaman Obat Multifungsi. Gaya Baru Pustaka. Jakarta

WHO, 2005. Guidelines For Laboratory and Field Testing of Mosquito. Geneva

Wijana, 1982. Beberapa Karakteristik Ae. aegypti Sebagai Vektor utama Demam Berdarah. Fakultas Kedokteran Universitas Udayan. Bali. 